\title{
Quantifying methane emissions from rice paddies in Northeast China by integrating remote sensing mapping with a biogeochemical model
}

\author{
Y. Zhang ${ }^{1}$, Y. Y. Wang ${ }^{2}$, S. L. Su ${ }^{3}$, and C. S. $\mathbf{L i}^{4}$ \\ ${ }^{1}$ Research Center of Remote Sensing \& Geoscience, Northeast Institute of Geography \& Agroecology, Chinese Academy of \\ Sciences, Changchun 130012, China \\ ${ }^{2}$ Research Center for Wetland Ecology and Environment, Northeast Institute of Geography \& Agroecology, Chinese \\ Academy of Sciences, Changchun 130012, China \\ ${ }^{3}$ College of Environmental \& Resources Sciences, Zhejiang University, Hangzhou 310029, China \\ ${ }^{4}$ Institute for the Study of Earth, Oceans, and Space, University of New Hampshire, Durham, NH 03824, USA
}

Received: 19 December 2010 - Published in Biogeosciences Discuss.: 14 January 2011

Revised: 4 May 2011 - Accepted: 16 May 2011 - Published: 23 May 2011

\begin{abstract}
The Sanjiang Plain located in Northeastern China is one of the major rice producing regions in the country. However, differing from the majority rice regions in Southern China, the Sanjinag Plain possesses a much cooler climate. Could the rice paddies in this domain be an important source of global methane? To answer this question, methane $\left(\mathrm{CH}_{4}\right)$ emissions from the region were calculated by integrating remote sensing mapping with a process-based biogeochemistry model, Denitrification and Decomposition or DNDC. To quantify regional $\mathrm{CH}_{4}$ emissions from the plain, the model was first tested against a two-year dataset of $\mathrm{CH}_{4}$ fluxes measured at a typical rice field within the domain. A sensitivity test was conducted to find out the most sensitive factors affecting $\mathrm{CH}_{4}$ emissions in the region. Based on the understanding gained from the validation and sensitivity tests, a geographic information system (GIS) database was constructed to hold the spatially differentiated input information to drive DNDC for its regional simulations. The GIS database included a rice map derived from the Landsat TM images acquired in 2006, which provided crucial information about the spatial distribution of the rice fields within the domain of 10.93 million ha. The modeled results showed that the total 1.44 million ha of rice paddies in the plain emitted $0.48-0.58 \mathrm{Tg} \mathrm{CH}_{4}-\mathrm{C}$ in 2006 with spatially differentiated annual emission rates ranging between $38.6-943.9 \mathrm{~kg} \mathrm{CH}_{4}$ $\mathrm{Cha}^{-1}$, which are comparable with that observed in Southern China. The modeled data indicated that the high SOC con-
\end{abstract}

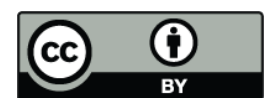

Correspondence to: Y. Y. Wang (wangyiyong@neigae.ac.cn) tents, long crop season and high rice biomass enhanced $\mathrm{CH}_{4}$ production in the cool paddies. The modeled results proved that the northern wetland agroecosystems could make important contributions to global greenhouse gas inventory.

\section{Introduction}

Among all of atmospheric components, methane $\left(\mathrm{CH}_{4}\right)$ is a major greenhouse gases (GHG). According to the Intergovernmental Panel on Climate Change (IPCC), the warming forces of $\mathrm{CH}_{4}$ are 25-30 times higher than that of $\mathrm{CO}_{2}$ per unit of weight based on 100-yr global warming potentials (IPCC, 2007). Although there is a significant declining trend in the rate of $\mathrm{CH}_{4}$ increase over the last two decades (Dlugokencky et al., 1998), atmospheric $\mathrm{CH}_{4}$ concentrations have risen to $1774 \mathrm{ppb}$ in 2005, which is more than doubled over the past 300 years (Blake and Rowland, 1998; Etheridge et al., 1992; IPCC, 2007). Agricultural activities are responsible for approximately $50 \%$ of global atmospheric inputs of $\mathrm{CH}_{4}$ (Scheehle and Kruger, 2006; USEPA, 2006), wherein the rice paddies have been identified as a major sources of atmospheric $\mathrm{CH}_{4}$. Over $10 \%$ of atmospheric $\mathrm{CH}_{4}$ was attributed to the emissions from global rice paddies (Neue, 1993; Scheehle and Kruger, 2006; USEPA, 2006). From the perspective of GHG mitigation, it also becomes a potential opportunity through reducing $\mathrm{CH}_{4}$ emissions from paddy fields (Oenema et al., 2001; Cole et al., 1996). Therefore, accurately estimating $\mathrm{CH}_{4}$ emissions from rice paddies has become important for GHG inventory or mitigation at country or regional levels.

Published by Copernicus Publications on behalf of the European Geosciences Union. 
China is an important rice producing country, which possesses approximately $20 \%$ of the world's rice paddies and produces $31 \%$ of the world's rice FAO, 2004). The 30 million ha of paddy rice cropland, accounting for $23 \%$ of all cultivated land in China (Frolking et al., 2002), is a large $\mathrm{CH}_{4}$ source. To estimate the national inventory of $\mathrm{CH}_{4}$ emission, researchers have conducted field campaigns in the major rice producing areas in Southern and Southeast of China (Cai et al., 1999, 2000). Results indicated high fluxes and spatial variations of $\mathrm{CH}_{4}$ emitted from the tested rice areas (Van Bodegom and Scholten, 2001; Verburg and Van Der Gon, 2001; Khalil et al., 1991; Yao et al., 1996; Cai et al., 2000). Attempts have been made to explain the regional variations of $\mathrm{CH}_{4}$ emissions although no concrete conclusions about the main controlling factors (Yao and Chen, 1994; Kern et al., 1997). Although traditional site-specific observation techniques like automatic closed chamber method have been recently improved for measuring $\mathrm{CH}_{4}$ emission at site scale, the regional or global estimation still remains as a question due to the lack of reliable methodologies (Verburg et al., 2006). Consequently, demands are arising for new methods such as model simulations to extrapolate the understandings gained at site scale to a large spatial dimension.

During the past two decades, many empirical and physical models have been developed to predict GHG emissions from rice fields. In a number of empirical models, the regression relationships between $\mathrm{CH}_{4}$ emission rate and rice biomass or yield were used to estimate $\mathrm{CH}_{4}$ production (Sinha, 1995; Kern et al., 1997; Anastasi et al., 1992). Although these empirical approaches were easy to use, the accuracy and precision of estimated results could not be ensured, and the variation in emissions at regional scale also couldn't be explained reasonably. Since many biogeochemical processes are involved in $\mathrm{CH}_{4}$ production, oxidation and emission, it would be difficult to predict the gas fluxes with oversimplified equations across a wide range of soil conditions and management practices. To meet the gaps, process-based biogeochemical models were developed to incorporate the comprehensive biogeochemical reactions and their environmental drivers. The major models that are able to simulate $\mathrm{CH}_{4}$ production include MEM (Cao et al., 1995a), MERES (Matthews et al., 2000), InfoCrop (Aggarwal et al., 2004), DNDC ( $\mathrm{Li}$ et al., 1992a) and so on. In recent years, these models played an important role in describing $\mathrm{CH}_{4}$ production and oxidation process in paddies and estimating the $\mathrm{CH}_{4}$ emissions at regional or global scales (Cao et al., 1995b, 1996; Bachelet and Neue, 1993; Li et al., 2004; Pathak et al., 2005; Zhang et al., 2009a). Among the candidate models, DNDC has been tested for the rice paddies in China and other Asian countries. We adopted DNDC in the study to implement the upscaling.

The Denitrification and Decomposition (DNDC) model is a generic model that simulates the biogeochemical processes leading to greenhouse gas emissions from soil. It is originally developed to model $\mathrm{N}_{2} \mathrm{O}$ emissions and SOC levels in the US cropping systems (Li et al., 1992a, 1992b, 1994), it has subsequently been adapted to model simulations of GHG emissions from a wide range of systems such like crop, pasture, rice paddy, and forest systems in a number of countries across the world (see a summary by Giltrap et al., 2010). As a process-based biogeochemical model, DNDC is able to track carbon $(\mathrm{C})$ and nitrogen $(\mathrm{N})$ cycles in agroecosystems driven by both the environmental factors and management practices. The DNDC has been tested against observed $\mathrm{CO}_{2}, \mathrm{~N}_{2} \mathrm{O}$ or $\mathrm{CH}_{4}$ fluxes from rice fields, and continuously improved based on comments or suggestions from a wide range of researchers worldwide during the past about 20 years (Zhang et al., 2002; Li et al., 2002, 2004; Cai et al., 2003). Calibration and validation of the model were performed for the US, China, Thailand, India, Japan and Italy with satisfactory results (Zheng et al., 1997; Li et al., 2002; Cai et al., 2003; Babu et al., 2005, 2006). Recently, Pathak et al. (2005) applied the DNDC model to estimate total GHG emissions from Indian rice paddies based on agricultural census data. And also, Zhang et al. (2009a) quantified $\mathrm{CH}_{4}$ emissions from rice fields in the Taihu Lake region in China using DNDC. These studies proved that DNDC is applicable for estimating $\mathrm{CH}_{4}$ emissions from rice paddies at regional scale.

In the study reported in the paper, we decided to take a new step to advance the DNDC regional applications. Remote sensing technology is capable of providing spatially explicit information of land surface in time. Remote sensing analysis could provide more accurate rice field area data to supplement the census data which are often inadequate or problematic. In fact, many researchers have utilized remotely sensed data (optical or microwave) for mapping the extent of paddy rice at local or regional scale (Frolking et al., 2002; Xiao et al., 2005; Le Toan et al., 1997; Ribbes and Le Toan, 1999; Zhang et al., 2009b). DNDC has been discussed for upsacling in add of the remote sensing technique to compile greenhouse gas inventories, identify spatial patterns in emission, or explore scenarios for mitigation (Takeuchi et al., 2001; Salas et al., 2007).

Except the introduction of remote sensing analysis into the DNDC upscaling, we selected a northern paddy rice domain in China, which possesses climate, soil and management conditions differing from that in the tropical or subtropical rice regions, which have been studied by other researchers.

\section{Method}

\subsection{Study area}

As target domain of this study, the Sanjiang Plain is located in northeast China. "Sanjiang" in Chinese means "Three Rivers", which represent Songhuajiang River, Wusulijiang River and Heilongjiang River, three major rivers whose watersheds cover almost the entire territory (10.93 million ha) 


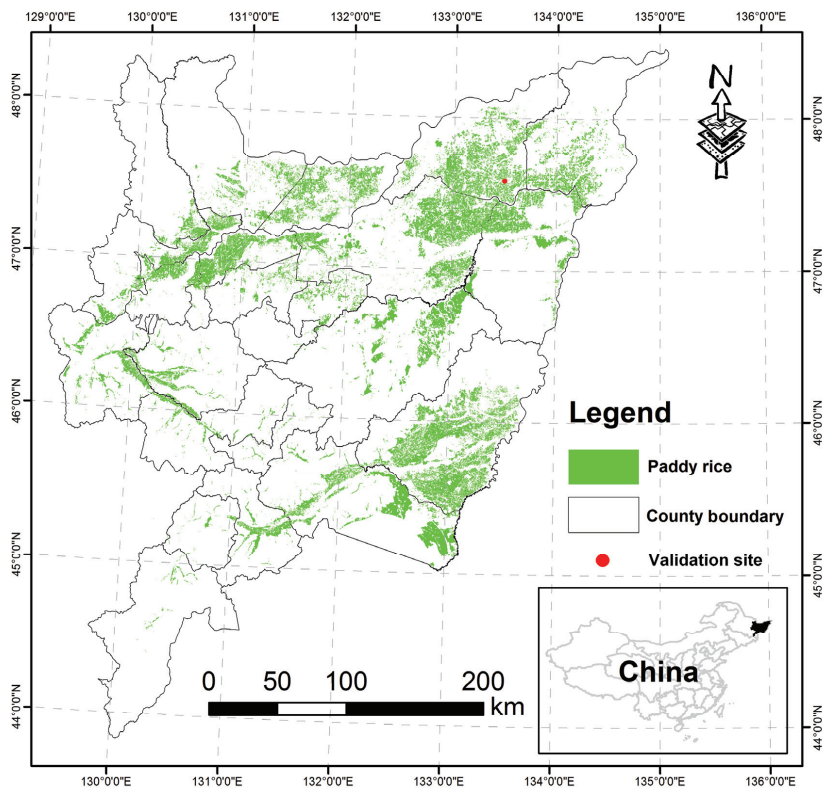

Fig. 1. Spatial distribution of paddy rice in the Sanjiang Plain in 2006.

Table 1. Remotely sensed imagery used for mapping rice paddy.

\begin{tabular}{lcc}
\hline Sensor & Path/Row No. & Acquisition date \\
\hline & $114 / 26$ & $30 / 08 / 2006$ \\
& $114 / 27$ & $30 / 08 / 2006$ \\
& $114 / 28$ & $30 / 08 / 2006$ \\
& $114 / 29$ & $30 / 08 / 2006$ \\
Landsat TM & $115 / 27$ & $22 / 09 / 2006$ \\
& $115 / 28$ & $22 / 09 / 2006$ \\
& $115 / 29$ & $22 / 09 / 2006$ \\
& $116 / 27$ & $31 / 08 / 2006$ \\
& $116 / 28$ & $31 / 08 / 2006$ \\
\hline
\end{tabular}

of the eastern part of Heilongiiang Province $\left(48.5^{\circ}-43.8^{\circ} \mathrm{N}\right.$ and $129.2^{\circ}-135.1^{\circ} \mathrm{E}$ ) (Fig. 1). This region lies at $45 \mathrm{~m}$ to $60 \mathrm{~m}$ geographic elevation above sea level with a gentle and flat topographic relief. Annual precipitation ranged from 310 to $750 \mathrm{~mm}$ during the period of 1980-2009. The local soils are fertile rich in soil organic matter. The flat topography, abundant precipitation and fertile soils have made the alluvial plain favorable for agricultural cultivation. In the 1970s reclamation campaigns were launched by the Chinese authorities to convert the natural swamplands into farmlands. Since then, the region has experienced drastic changes in the land use. For example, the rice fields have increased from zero to 1.44 million ha during the past about 40 years. The rice fields are the rice-producing region with the highest latitude in not only China but also the world.
The rice is planted as a single-season crop in the region. Continuously flooding is extensively practiced in the rice fields. Urea and synthetic fertilizer are predominantly applied without any organic matter amended. The rice straw is normally left as stubble in the fields after harvest in October, and the stubble is incorporated into the soils with tillage before the beginning of the next rice season.

\subsection{Model validation tests}

To validate the DNDC model for its applicability for the rice fields in the Sanjiang Plain, field experiments were conducted at a paddy rice site in the Honghe Farm (at $47^{\circ} 35 / \mathrm{N}$ and $133^{\circ} 31 /$ E) within the plain (Fig. 1). Two-year (2004 and 2006) experiments were conducted in a same paddy field with three treatments. In 2004, the field was treated with two fertilizer application rates, i.e., 60 and $150 \mathrm{~kg} \mathrm{~N} \mathrm{ha}^{-1}$ (C04$\mathrm{N} 60$ and $\mathrm{C} 04-\mathrm{N} 150)$; in 2006, only one application rate, $150 \mathrm{~kg} \mathrm{~N} \mathrm{ha}^{-1}$ (C06-N150), was applied. For C04-N60, the $60 \mathrm{~kg} \mathrm{~N}$ of synthetic fertilizer was split into two applications at the rice transplanting $\left(24 \mathrm{~kg} \mathrm{Nha}^{-1}\right)$ and in the tillering stage $\left(36 \mathrm{~kg} \mathrm{Nha}^{-1}\right)$. The same split method was also applied for the rate of $150 \mathrm{~kg} \mathrm{~N} \mathrm{ha}^{-1}$ (Table 2). $\mathrm{CH}_{4}$ fluxes were measured with chamber method $(0.5 \mathrm{~m} \times 0.5 \mathrm{~m})$ with automated opening and closure. The $\mathrm{CH}_{4}$ measurements were conducted twice per week through the whole rice-growing period (from late May to early October) (see details in Wang et al., 2008). The measured data of $\mathrm{CH}_{4}$ fluxes were used to calibrate/validate the DNDC model. Daily meteorological data (air temperature and precipitation) were acquired from the local climate station, a part of the Ecological Experimental Station of Mire-Wetland in the Sanjiang Plain run by the Chinese Academy of Science. Soil properties were obtained from the ground-based measurements, and agricultural management information was collected based on the local farming practices (see details in Tables 2 and 3).

DNDC simulates $\mathrm{CH}_{4}$ production mainly based on four factors, i.e., the soil redox potential (Eh), soil C sources (DOC and $\mathrm{CO}_{2}$ ) available for the methanogens, soil temperature, and $\mathrm{CH}_{4}$ diffusion rate which is controlled by the plant conductivity (aerenchyma) and soil texture ( $\mathrm{Li}, 2000)$. Among the factors, plant (i.e., rice) growth plays a key role in determining the soil $\mathrm{C}$ availability. So, the parameters defining the rice growth in DNDC were first calibrated against observed crop biomass/yield data. Using the turn-and-adjust method, we obtained a set of physiological and phenology parameters for the rice cultivar (Kongyu-131) which was widely planted in the Sanjiang Plain. The calibrated crop parameters are listed in Table 4. With the crop parameters, DNDC correctly simulated the crop biomass growth and yield and hence set a sound basis to quantify the root exudation and respiration, which provided $\mathrm{DOC}$ and $\mathrm{CO}_{2}$ to the soil methanogens. 
Table 2. Management information on the rice paddies at study sites in Sanjiang Plain of Northeast China.

\begin{tabular}{|c|c|c|c|}
\hline Mode & C04-N60 & $\mathrm{C} 04-\mathrm{N} 150$ & C06-N150 \\
\hline Tillage & 5/15: Plow depth of $30 \mathrm{~cm}$ & 5/15: Plow depth of $30 \mathrm{~cm}$ & 5/14: Plow depth of $30 \mathrm{~cm}$ \\
\hline Rice cultivation & $5 / 25-9 / 29$ & $5 / 25-9 / 29$ & $5 / 24-9 / 24$ \\
\hline Flooding & $\begin{array}{l}5 / 15-8 / 23 \text { : Continuously } \\
\text { flooding, water depth } \\
\text { of } 5-10 \mathrm{~cm}\end{array}$ & $\begin{array}{l}5 / 15-8 / 23 \text { : Continuously } \\
\text { flooding, water depth } \\
\text { of } 5-10 \mathrm{~cm}\end{array}$ & $\begin{array}{l}5 / 14-8 / 28: \text { Continuously } \\
\text { flooding, water depth } \\
\text { of } 5-10 \mathrm{~cm}\end{array}$ \\
\hline Fertilization & $\begin{array}{l}\text { 6/13: Synthetic fertilizer } \\
\left(24 \mathrm{~kg} \mathrm{~N} \mathrm{ha}^{-1}\right) ; 6 / 28 \text { : } \\
\text { Synthetic fertilizer }\left(36 \mathrm{~kg} \mathrm{Nha}^{-1}\right)\end{array}$ & $\begin{array}{l}\text { 6/13: Urea + Synthetic } \\
\text { fertilizer }\left(60 \mathrm{~kg} \mathrm{~N} \mathrm{ha}^{-1}\right) ; \\
\text { 6/28: Urea }\left(90 \mathrm{~kg} \mathrm{Nha}^{-1}\right)\end{array}$ & $\begin{array}{l}\text { 5/24: Urea + Synthetic } \\
\text { fertilizer }\left(60 \mathrm{~kg} \mathrm{~N} \mathrm{ha}^{-1}\right) ; 7 / 2 \text { : } \\
\text { Urea }\left(90 \mathrm{~kg} \mathrm{~N} \mathrm{ha}^{-1}\right)\end{array}$ \\
\hline Manure application & No & No & No \\
\hline Residues management & $\begin{array}{l}\text { Fraction of residues left } \\
\text { in fields: } 20 \%\end{array}$ & $\begin{array}{l}\text { Fraction of residues left } \\
\text { in fields: } 20 \%\end{array}$ & $\begin{array}{l}\text { Fraction of residues left } \\
\text { in fields: } 20 \%\end{array}$ \\
\hline
\end{tabular}

Table 3. Inputs used to test the DNDC model and baseline values for sensitivity tests in the validated sites of rice paddies.

\begin{tabular}{llll}
\hline Environmental Factors & & Baseline value & Range tested \\
\hline \multirow{2}{*}{ Climate } & Annual mean temperature $\left({ }^{\circ} \mathrm{C}\right)$ & 2.4 & $0.4-4.4$ \\
& Total annual precipitation $(\mathrm{mm})$ & 560 & $448-672$ \\
& Clay fraction $(\%)$ & 0.41 & $0.1-0.6$ \\
& Field capacity $(\%)$ & 0.57 & Not varied \\
& Wilting point $(\%)$ & 0.27 & Not varied \\
Soil Property & Porosity (\%) & 0.59 & Not varied \\
& Initial soil C fraction $\left(\mathrm{kg} \mathrm{C} \mathrm{kg}^{-1}\right.$ soil) & 0.0277 & $0.01-0.07$ \\
& Bulk density $\left(\mathrm{g} \mathrm{cm}^{-3}\right)$ & 0.98 & $0.8-1.6$ \\
& Soil pH & 5.61 & $5.0-9.0$ \\
& Depth of continuous flooding water $(\mathrm{cm})$ & 10 & Not varied \\
& Drained days (d) & 0 & $2-12$ \\
Management Practices & Fraction of rice residue left in field $(\%)$ & 20 & $0-100$ \\
& N-Fertilizer application $\left(\mathrm{kg} \mathrm{N} \mathrm{ha}^{-1}\right)$ & 60 & $60.0-150.0$ \\
\hline
\end{tabular}

For the model validation, the local climate, soil and farming management data were utilized to compose input scenarios, which were used to run DNDC for the experimental site. The measured $\mathrm{CH}_{4}$ flux data were used to compare with the modeled $\mathrm{CH}_{4}$ fluxes at daily time step as well as for the seasonal total emissions. Statistical tools such as the root mean square error (RMSE), the coefficient of model efficiency (EF) and the coefficient of model determination (CD) were adopted to assess the "goodness of fit" of model predictions (see details in Smith et al., 1997). The three "goodness of fit" measures were calculated separately as below:

$\mathrm{RMSE}=\sqrt{\frac{\left(F_{\text {simulated }}-F_{\text {observed }}\right)^{2}}{n}}$

$$
\begin{aligned}
\mathrm{EF} & =\frac{\sum_{i=1}^{n}\left(O_{i}-\bar{O}\right)^{2}-\sum_{i=1}^{n}\left(S_{i}-O_{i}\right)^{2}}{\sum_{i=1}^{n}\left(O_{i}-\bar{O}\right)^{2}} \\
\mathrm{CD} & =\sum_{i=1}^{n}\left(O_{i}-\bar{O}\right)^{2} / \sum_{i=1}^{n}\left(S_{i}-\bar{O}\right)^{2}
\end{aligned}
$$

Where, $F_{\text {simulatied }}$ and $F_{\text {observed }}$ in Eq. (1) denotes the simulated and the observed $\mathrm{CH}_{4}$ fluxes at validation sites; $n$ is the total number of observations. In Eq. (2 and 3), $O_{i}$ are the observed $\mathrm{CH}_{4}$ fluxes, $\bar{O}$ is the mean of the observed $\mathrm{CH}_{4}$ fluxes, $S_{i}$ are the simulated $\mathrm{CH}_{4}$ fluxes, and $n$ is the number of paired values. Value for EF is less than or equal to 1. A positive value indicates that the simulated values describe the trend in the measured data better than the mean of the observed values. The CD value is larger than or equal 
to 0 . When a $C D$ value of 1 or above, it indicates that the model describes the measured data better than the mean of the observations. Taken together, EF and CD allow RMSE to be further interpreted where standard error values of the measurements are unavailable.

\subsection{Model sensitivity test}

Methane emissions from rice fields are controlled by many factors (Yan et al., 2005). However, some factors could be more sensitive than others. A sensitivity test was conducted with DNDC to find out the most sensitive factors for $\mathrm{CH}_{4}$ emissions from the Sanjiang Plain. The baseline scenario was set based on the actual climate, soil and management conditions at the experimental site in the Sanjiang Plain. In the test, we varied climate variables (temperature or precipitation), soil properties (SOC content, clay fraction, $\mathrm{pH}$ and bulk density), or agricultural management practices (flooding regime, residue management and $\mathrm{N}$-fertilizer application rate). The sensitivity test was conducted by varying a single input parameter in a predefined range while keeping all other input parameters constant. All the parameters for sensitivity analysis were listed in Table 3 . The model responses to changes of these factors on $\mathrm{CH}_{4}$ emissions were presented respectively in Fig. 2.

The likely response of $\mathrm{CH}_{4}$ emission to changes in climate was investigated by running DNDC using alternative climate scenarios. Precipitation was either increased or decreased by $20 \%$ of the baseline value $\left(\sim 560 \mathrm{~mm} \mathrm{yr}^{-1}\right)$; and temperature was varied by 1 or $2{ }^{\circ} \mathrm{C}$. The modeled results indicated that (1) the precipitation changes had was insignificant or negligible impact on $\mathrm{CH}_{4}$ emissions (Fig. 2a), and (2) the higher temperature elevated $\mathrm{CH}_{4}$ emissions due to the accelerated soil organic matter (SOM) decomposition and fermentation process (Fig. 2b). The results are in agreement with previous studies reported by other researchers (e.g., Cao et al., 1998).

Four soil properties (SOC content, clay fraction, $\mathrm{pH}$ and bulk density) were investigated in the sensitivity test. The results showed that (1) soil texture was the most sensitive factor due to its effects on the soil anaerobic status: the clay loam soil was more likely to produce more $\mathrm{CH}_{4}$ than the sandy soil (Fig. 2c), and (2) SOC content was the second most sensitive factor due its effects on the soil DOC availability as well as the methanogen population (Fig. 2f). The modeled results in line with observations reported by other researchers (Yagi and Minami, 1990; Wassmann et al., 1998; HolzapfelPschorn and Seiler, 1986; Li et al., 2004).

In rice paddy, flooding regime, residue management and application rate of $\mathrm{N}$-fertilizer are three major anthropogenic activities affecting not only rice productivity but also GHG emissions. Figure 2 shows that when the draining time duration for the mid-season drainage increased to 10 days, the $\mathrm{CH}_{4}$ emission was reduced by $25 \%$ (Fig. $2 \mathrm{~g}$ ). This trend has been reported in many studies (Sass et al., 1992; Yagi et al., 1996; Li et al., 2006). In the test, crop straw incorporation

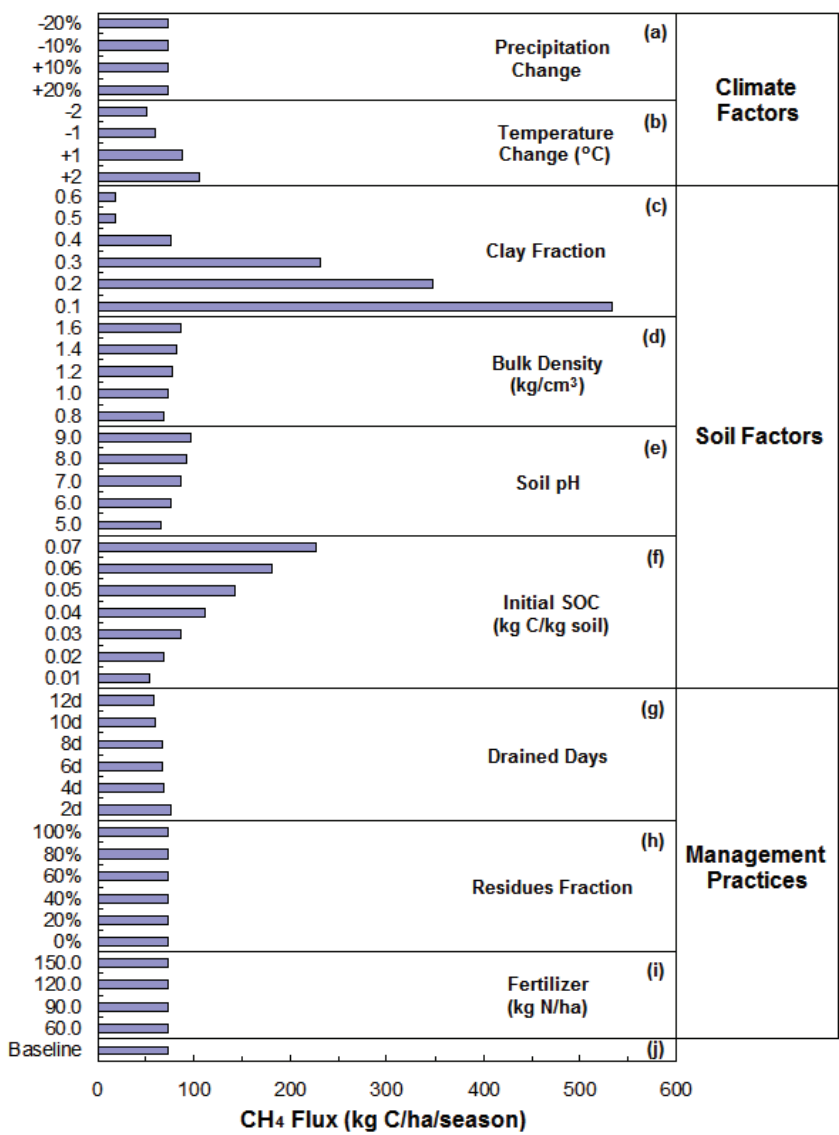

Fig. 2. Sensitivity tests of environment factors driving $\mathrm{CH}_{4}$ emissions from rice paddies.

didn't show strong effect on $\mathrm{CH}_{4}$ emission. The modeled results indicated that in the one-year simulation, the straw was incorporated at the end of the rice season when the soil was drained already (Fig. 2h). The variation in fertilizer application rate didn't show strong impact on $\mathrm{CH}_{4}$ emission either (Fig. 2i).

The sensitivity test provided crucial information for regional simulations as we learnt which input parameters could most sensitively affect the modeled results and hence should be paid with the greatest considerations.

\subsection{Regional database}

A geographic information system (GIS) database was constructed to hold all the input information required for upscaling DNDC simulations to the Sanjinag Plain. The database included a rice field map, soil properties, daily weather data, and farming management practices. The rice map was obtained through remote sensing analysis.

To estimate the $\mathrm{CH}_{4}$ emissions from the target domain, it is necessary to acquire detailed and accurate spatial distribution of paddies. Remotely sensed data were often classified to map the spatial pattern of rice paddies and calculate 
Table 4. The calibrated crop parameters of rice for regional simulation of DNDC.

\begin{tabular}{lc}
\hline Crop parameters & Value \\
\hline Total biomass $\left(\mathrm{kg} \mathrm{C} \mathrm{ha}^{-1}\right)$ & 4383.8 \\
Grain fraction of total biomass (\%) & 47.0 \\
Shoot fraction of total biomass (\%) & 43.0 \\
Root fraction of total biomass (\%) & 10.0 \\
$\mathrm{C} / \mathrm{N}$ ratio for plant & 58.3 \\
$\mathrm{C} / \mathrm{N}$ ratio for grain & 55.0 \\
$\mathrm{C} / \mathrm{N}$ ratio for shoot (leaf + stem) & 60.0 \\
C/N ratio for root & 70.0 \\
Water demand (g water/g dry matter) & 508.0 \\
Maximum leaf area index & 6.0 \\
Maximum height of plant (m) & 1.0 \\
Temperature degree days for maturity (TDD) $\left({ }^{\circ} \mathrm{C}\right)$ & 2300.0 \\
N fixation index & 1.0 \\
Valscularity index $(0-1)$ & 1.0 \\
\hline
\end{tabular}

the rice areas. In this study the Landsat thematic mapper (TM) imagery acquired from the EarthExplorer Interface (http://edcsns17.cr.usgs.gov/EarthExplorer/) were processed to extract the spatial distribution of rice paddies in the Sanjiang Plain (Table 1). Total of 9 clear TM images covering the target domain acquired in the near-maturing stage of rice in 2006 were selected to extract a single class paddy rice with elaborately image preprocessing such as mosaicking, subsetting and geometric correction at stepwise. Visual interpretation was applied for ensuring accurate delineation of rice paddies at the processing software environment of ArcGIS 9.0, although time-expensive. The vectorized rice paddy polygons then were segmented by soil data with cell size of $10 \mathrm{~km} \times 10 \mathrm{~km}$. Within each cell, rice area was calculated for estimating $\mathrm{CH}_{4}$ emissions seasonally conducted in following sections. Due to the clear weather conditions and the distinguished phenology features, the rice fields were successfully extracted from remote sensing data. The formed rice map had a high spatial resolution of $30 \mathrm{~m}$. The data set provided a sound basis for delineating the rice paddies in the study region with a high accuracy and a high precision.

Daily climate data (maximum and minimum air temperature, precipitation and mean wind speed) were acquired for 2004 and 2006 from seven weather stations (China Meteorological Data Sharing Service System at http://data.cma. gov.cn/) within the target domain. Soil data were derived from the soil dataset developed by the Institute of Soil Science, Chinese Academy of Sciences, which was compiled based on the second national soil survey conducted in 19801990s. The soil dataset contains multi-layer soil properties (e.g. organic matter, $\mathrm{pH}$ and bulk density), soil texture (sand, silt and clay) and other spatial information (Shi et al., 2004; Yu et al., 2007) with a resolution of $10 \mathrm{~km} \times 10 \mathrm{~km}$. In this study, we adopted the top $(0-10 \mathrm{~cm})$ soil data derived from
805 paddy profiles within the domain to serve the DNDC simulations. Detailed management practices on rice cultivation were investigated by communicating with a number of local agronomists and farmers. All the spatially differentiated input information was composed in the GIS database, which was then linked to DNDC through the DNDC's regional mode interface.

DNDC was run for the Sanjiang Plain twice with 2004 and 2006 climate data, respectively. During the model runs, DNDC performed simulation for each grid cell twice with the maximum and minimum values of the soil properties, respectively. The two simulations produced a pair of $\mathrm{CH}_{4}$ fluxes for each grid cell, which formed a range of $\mathrm{CH}_{4}$ emission that was later used for quantifying the uncertainty generated from the upscaling (please refer $\mathrm{Li}$ et al., 2004 for details of the Most Sensitive Factor method). Based on the modeled $\mathrm{CH}_{4}$ emission rate and the rice field acreage for each grid cell, the total $\mathrm{CH}_{4}$ emissions from the cell could be calculated. The regional emission was calculated by summing up the $\mathrm{CH}_{4}$ emissions from all the grid cells within the domain. The Sanjiang Plain contains 23 counties; the countylevel $\mathrm{CH}_{4}$ emissions were also calculated for evaluating the spatial patterns of $\mathrm{CH}_{4}$ emissions in the plain.

\section{Results}

\subsection{Paddy rice map of the Sanjiang Plain}

With visual interpretation technique, the rice paddy cover in the domain in 2006 was mapped based on 9 clear TM images (Fig. 1). The rice paddies were mainly distributed in the lowland areas along with the major rivers. The total area of paddy fields was 1.44 million ha in 2006, which was approximately $35 \%$ higher than that in 2000 . This result confirmed the census reports that rice paddies rapidly increased in the Sanjiang Plain in the past ten years.

\subsubsection{Validation of simulated results}

The measured $\mathrm{CH}_{4}$ fluxes at the three treatments, $\mathrm{C} 04-\mathrm{N} 60$, C04-N150 and C06-N150, were compared with modeled results. Figure 3 shows the comparisons between the modeled $\mathrm{CH}_{4}$ fluxes with observations. As a whole, the modeled results showed a fair agreement with observations although minor discrepancies exist across the three treatments (Fig. 3a1, b1, c1). Regression analysis demonstrated that the simulated emissions explained over $85 \%$ of the variation in observed emissions for all the three cases. The intercept of three regression lines is very closer to 0 . The RMSE values for the three cases are $0.190,0.304$ and 0.344 for C04-N60, C04N150 and C06-N150, respectively (Fig. 3a2, b2, c2). In the validation test, the significance test of difference in between modeled and observed $\mathrm{CH}_{4}$ fluxes showed that all the possibility ("P" in Fig. 3) values of three treatments $(0.972$ for C04-N60, 0.646 for C04-N150 and 0.290 for C06-N150) are 

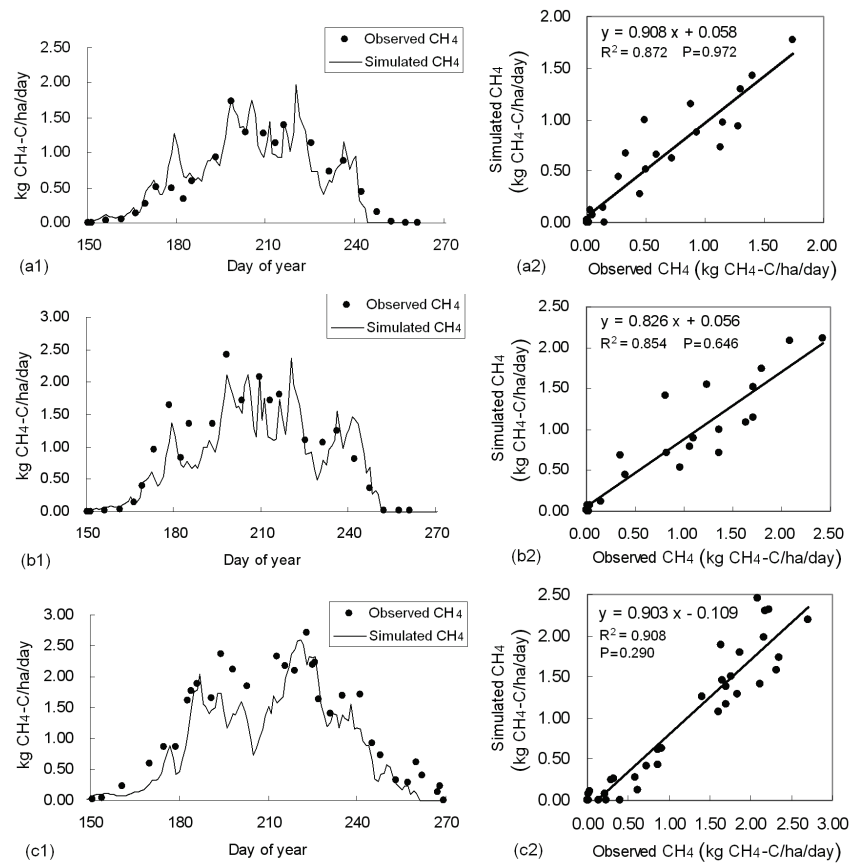

Fig. 3. Simulated vs. observed $\mathrm{CH}_{4}$ fluxes in validation site with three $\mathrm{N}$-fertilizer application scenarios: $60 \mathrm{~kg} \mathrm{Nha}^{-1}$ (a1 and a2) and $150 \mathrm{~kg} \mathrm{Nha}^{-1}$ (b1 and b2) in 2004, and $150 \mathrm{~kg} \mathrm{Nha}^{-1}$ (c1 and c2) in 2006, respectively.

Table 5. Statistical analysis for comparison of the simulated and observed $\mathrm{CH}_{4}$ fluxes in three case studies.

\begin{tabular}{lcccccc}
\hline Mode & $\begin{array}{c}\text { Measurement } \\
\text { Number }\end{array}$ & Slope & Intercept & RMSE & EF & CD \\
\hline C04-N60 & 24 & 0.908 & 0.058 & 0.190 & 0.870 & 1.058 \\
C04-N150 & 24 & 0.826 & 0.056 & 0.304 & 0.837 & 1.227 \\
C06-N150 & 35 & 0.903 & -0.109 & 0.344 & 0.844 & 1.041 \\
\hline
\end{tabular}

far larger than 0.05. It means that the differences in modeled and observed values are not significant at confidence level of $95 \%$. Furthermore, all three EF are positive ( $>0.8)$, and three $\mathrm{CD}$ are greater than 1 (Table 5). The results thus indicated that DNDC is capable of capturing the seasonal patterns as well as the magnitudes of $\mathrm{CH}_{4}$ emissions from the experimental site in the Sanjinag Plain.

\subsection{Estimation of $\mathrm{CH}_{4}$ emissions for the Sanjiang Plain}

Linked to the GIS database, DNDC was run across the entire 1.44 million ha of rice fields in the Sanjiang Plain. The modeled results were summed up to produce regional $\mathrm{CH}_{4}$ emissions. The spatial and temporary patterns of $\mathrm{CH}_{4}$ emissions in the domain are discussed as follows.

Results from the regional simulations indicated that the total $\mathrm{CH}_{4}$ emissions from the Sanjiang Plain ranged from
Table 6. Simulated results of $\mathrm{CH}_{4}$ emissions from paddies of the Sanjiang Plain.

\begin{tabular}{llccc}
\hline Mode & & C04-N60 & C04-N150 & C06-N150 \\
\hline Emission rates & Mean & 381.24 & 386.93 & 416.48 \\
$\left(\mathrm{~kg} \mathrm{CH}_{4}-\mathrm{Cha}^{-1}\right)$ & Maximum & 926.37 & 927.04 & 943.88 \\
& Minimum & 32.30 & 32.23 & 38.59 \\
& & 0.48 & 0.49 & 0.53 \\
Total emissions & Mean & 0.52 & 0.53 & 0.58 \\
$\left(\mathrm{Tg} \mathrm{CH}_{4}-\mathrm{C}\right)$ & Maximum & 0.43 & 0.44 & 0.48 \\
& Minimum & 0. & \\
\hline
\end{tabular}

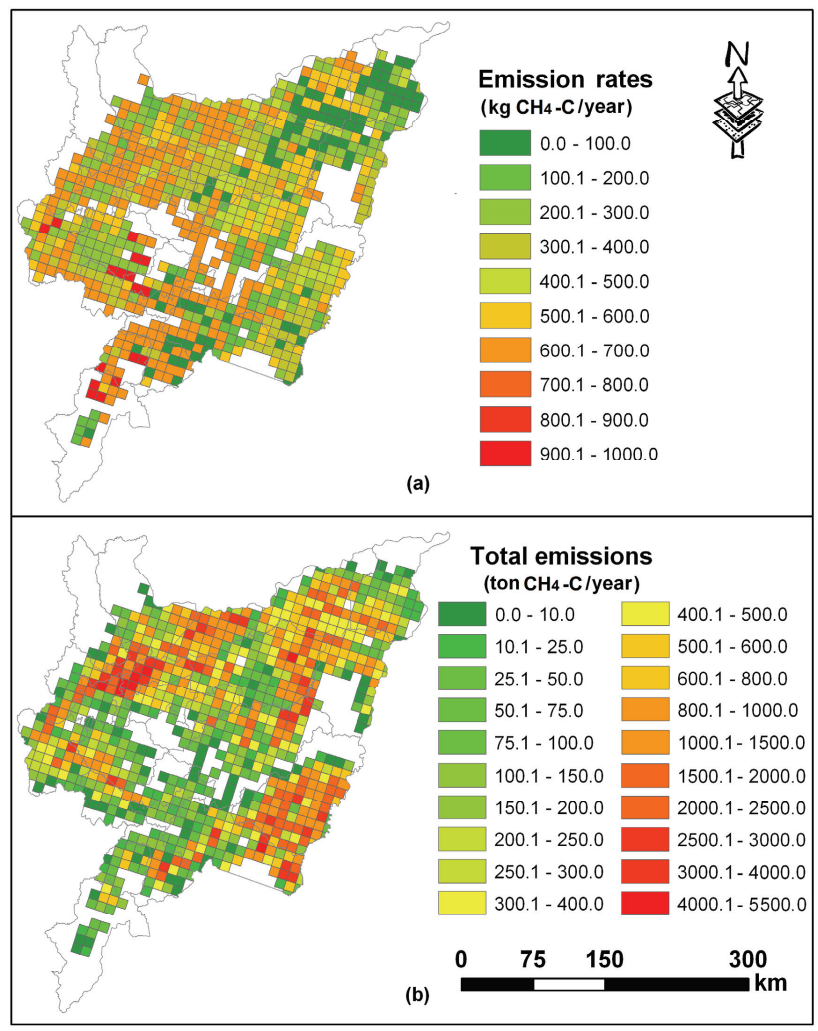

Fig. 4. Mean $\mathrm{CH}_{4}$ emission rates (a) and total emissions (b) per year from paddy fields in the Sanjiang Plain at scale of $10 \mathrm{~km} \times 10 \mathrm{~km}$ grid-cell in 2006 .

0.43 to 0.58 (or $0.51 \pm 0.07$ ) $\mathrm{Tg} \mathrm{CH}_{4}-\mathrm{C} \mathrm{yr}^{-1}$. Figure 4 show $\mathrm{CH}_{4}$ emission rates and total emissions at the grid-cell scale. The two maps showed clear spatial variations in $\mathrm{CH}_{4}$ emissions across the domain region. The emission rates varied between $<40$ and $>900 \mathrm{~kg} \mathrm{CH}_{4}-\mathrm{C} \mathrm{ha}^{-1}$ mainly driven by the spatial variation in the soil properties (Fig. 4a; Table 6). In terms of sensitive analysis shown in Fig. 2, the spatial variations in $\mathrm{CH}_{4}$ emission rates mainly are attributed to the Most Sensitive Factor (MSF) soil properties (i.e., soil texture and SOC content). Statistical analysis showed that the lowest $\mathrm{CH}_{4}$ flux (38.59 $\mathrm{kg} \mathrm{CH}_{4}-\mathrm{C} \mathrm{ha}^{-1}$ ) was located at three soil grid cells with the maximum clay fraction in soil of $0.581 \%$. 
However in those soil grids with the minimum of clay fraction $(0.131 \%)$, the $\mathrm{CH}_{4}$ flux was not necessarily the highest values (943.88 $\mathrm{kg} \mathrm{CH}_{4}-\mathrm{Cha}^{-1}$ ). They occurred in those with the highest SOC content $(6.7 \%)$. Consequently, the clay fraction in soil and SOC content was the most sensitive factor driving the $\mathrm{CH}_{4}$ emission rates (Fig. 2). In contrast, other soil properties like bulk density and soil $\mathrm{pH}$, were less sensitive to the $\mathrm{CH}_{4}$ emission from rice paddy.

The regional average was around $400 \mathrm{~kg} \mathrm{CH}_{4}-\mathrm{Cha}^{-1}$ in 2006, which was higher than that $\left(15-198 \mathrm{~kg} \mathrm{CH}_{4}\right.$ $\mathrm{C} \mathrm{ha}^{-1} \mathrm{yr}^{-1}$ ) observed in the Southeast China such as Taihu Lake region (Zhang et al., 2009a) and also higher than the default emission factors of $200 \mathrm{~kg} \mathrm{CH}_{4}-\mathrm{C} \mathrm{ha}^{-1}$ season $^{-1}$ suggested by the IPCC guidelines (IPCC, 1997). The simulated data attributed the high $\mathrm{CH}_{4}$ emission rates to the SOC rice soils (averagely $0.31 \mathrm{~kg} \mathrm{C} \mathrm{kg}^{-1}$ soil) in combination with the continuous flooding management in the Sanjiang Plain. Following the SOC content trend, the modeled $\mathrm{CH}_{4}$ emission rates gradually decreased from the southwest to the northeast of the region (Fig. 4a). The maximum $\mathrm{CH}_{4}$ emission rates $\left(\sim 944 \mathrm{~kg} \mathrm{CH}_{4}-\mathrm{Cha}^{-1}\right)$ were shown in five grid cells in the southwestern part of the domain apparently related to the higher SOC contents in the region. Differing from the $\mathrm{CH}_{4}$ emission rate, the total $\mathrm{CH}_{4}$ emission flux for each grid cell was not only related to the emission rate but also the total rice area. In 2006, the total $\mathrm{CH}_{4}$ emissions over the entire Sanjiang Plain were ranged from 0.48 to $0.58 \mathrm{Tg} \mathrm{CH}_{4}$ $\mathrm{C}$, the mean emission was $0.53 \mathrm{TgCH}_{4}$-C. In general, the mid-northern and southeastern parts of the Sanjiang Plain had more expansive rice paddies and hence possessed higher $\mathrm{CH}_{4}$ emissions (Fig. 4b).

The Sanjiang Plain contains 23 administrative counties, where a small population of farmer owes a large amount of agro-lands, and modern cultivation managements are very extensively practiced. Generally speaking, unlike the South China, only single season rice were grown in the Northeast China, and the management practices are relatively identical within the entire study area. The indistinctive differences in rice cultivation practices make less variation in $\mathrm{CH}_{4}$ emissions from rice paddy in this study area, which has been showed in sensitivity tests of environment factors driving $\mathrm{CH}_{4}$ emissions (Fig. 2). Therefore, we assumed the general (or average) management practices were identical cover the entire study area. The climate conditions are not homogeneous but very similar cover the study area so that their effects on $\mathrm{CH}_{4}$ emission rate are negligible. The county-level $\mathrm{CH}_{4}$ emissions in 2006 are shown in Fig. 5. The high emission counties such as Fujin (FJ), Huachuan (HC) and Hulin (HL) are located either in mid-northern or southeastern parts of the domain. In contrast, the low emission counties such as Shuangyashan (SYS), Youyi (YY), Qitaihe (QTH), Jixi (JX), Muling (ML) and Hegang (HG) are located in either the central-southern or the northwestern areas of the plain (Fig. 5a). The highest $\mathrm{CH}_{4}$ emission $\left(81.8 \mathrm{Gg} \mathrm{CH}_{4}\right.$-C) was in the $\mathrm{HC}$ and HL Counties, and the lowest $\left(0.683 \mathrm{Gg} \mathrm{CH}_{4}-\right.$
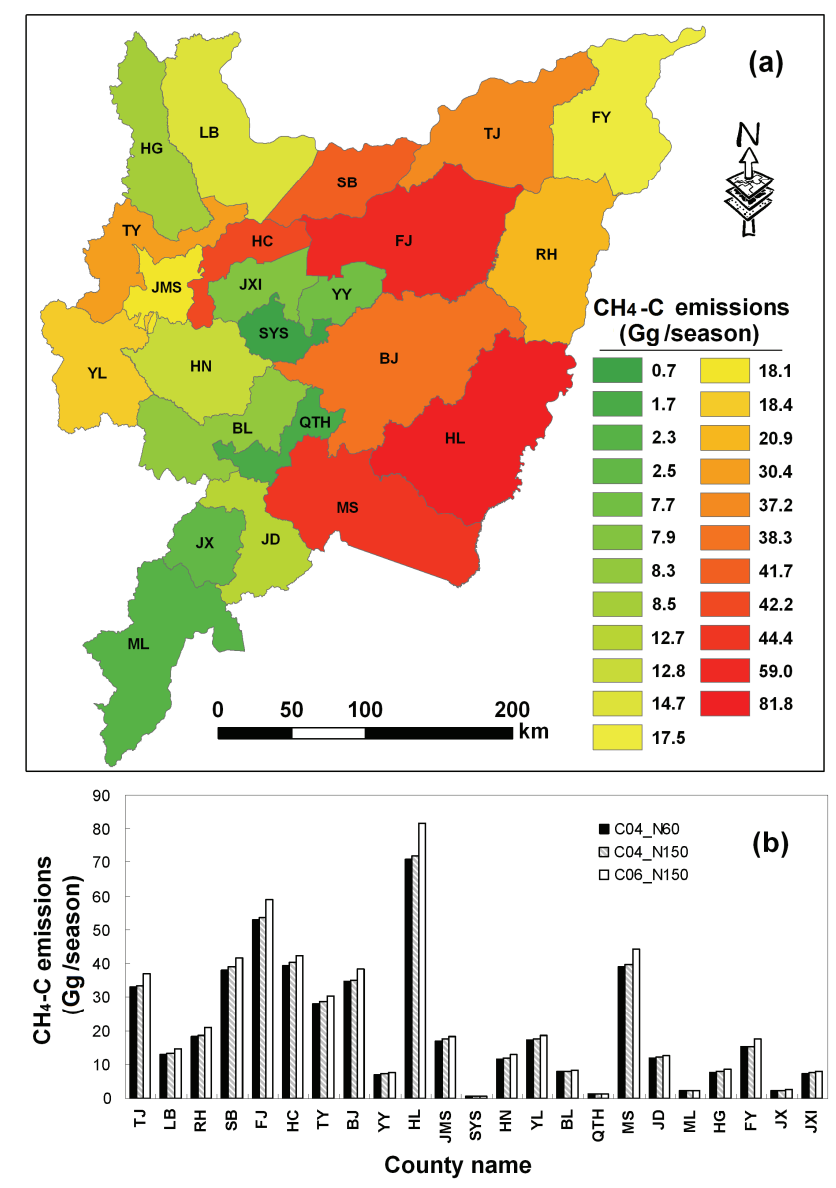

Fig. 5. Total $\mathrm{CH}_{4}$ emissions per year from rice paddies in the Sanjiang Plain at county-level scale. Where, (a) denotes the spatial distribution of total emissions in 2006, and (b) is the comparison of $\mathrm{CH}_{4}$ emissions at three scenarios of C04-N60, C04N150 and C06N150.

C) was in the ML County. Statistic results showed that the highest emission county emitted over 100 times higher than the lowest one per season (Fig. 5b). Such a huge difference in $\mathrm{CH}_{4}$ emission was due to the variations in the total paddy cultivation acreage as well as the $\mathrm{CH}_{4}$ emission rate determined by the soil properties (e.g. SOC content, clay fraction in soil, etc.).

In addition, attempt was also made to estimate the total $\mathrm{CH}_{4}$ emissions in 2004 based on the assumption of same rice areas as in 2006. Simulated results showed that at two scenarios, C04-N60 and C04-N150, both of the emission rates and total emissions of each county were less than that in 2006 (Fig. 5b). The total emissions were very similar, mean of 0.48 and $0.49 \mathrm{Tg} \mathrm{CH}_{4}-\mathrm{C}$ was separately emitted for $\mathrm{C} 04-$ N60 and C04-N150 case in 2004 (Table 6). This difference was apparently related to the climate data and management practices (e.g. flooding regime and $\mathrm{N}$-fertilizer application rate, etc.) of the two years. By comparing the daily mean temperatures during the rice-growing seasons in 2004 and 
2006, we found the average temperature in the 2006 growing season was $0.26^{\circ} \mathrm{C}$ higher that that in 2004 . The regional simulations indicated that although the change in $\mathrm{N}$-fertilizer application rate didn't affect the regional $\mathrm{CH}_{4}$ emissions very much, it did increase the crop yields that could indirectly enhance the $\mathrm{CH}_{4}$ production.

\section{Discussions}

The Sanjiang Plain possesses 1.44 million ha of paddy rice in the very northeastern part of China in 2006 where the annual mean temperature is $2.2^{\circ} \mathrm{C}$, which is $10-15^{\circ} \mathrm{C}$ lower than that in the majority rice producing areas in the southeastern or southwestern part of the country. Driven by the market demand for high quality rice in China, more upland croplands planted with corn or soybeans were converted to wetland crops (mainly rice) in Northern China during the past decade. This kind of rapid land-use transformation could alter the national GHG inventory now and in the near future. Mapping the new land-use as well as the consequent GHG emissions should be an urgent task for the researchers.

DNDC was first utilized to estimate $\mathrm{CH}_{4}$ emissions from this high latitude rice fields. After the calibration and validation against local observations, DNDC simulated $\mathrm{CH}_{4}$ fluxes across the target domain. The modeled $\mathrm{CH}_{4}$ emission rates varied in a range of $100-800 \mathrm{~kg} \mathrm{Cha}^{-1}$ per year, which is consistent with the $\mathrm{CH}_{4}$ emission rates observed or modeled in the southern rice regions in China. Our modeled results are supported by observations conducted in a number of high latitude wetlands where the researchers measured high fluxes of $\mathrm{CH}_{4}$ from the cold, even frozen, wetland ecosystems. Our results confirmed the hypothesis that the high latitude wetlands could be an important $\mathrm{CH}_{4}$ source maybe due to adaptation of the methanogens to the low temperatures.

In this study, we utilized a remote sensing-derived crop map to drive a process-based biogeochemistry model to realize the regional quantification. The uncertainty produced from the upscaling has been estimated with the Most Sensitive Factor method developed by $\mathrm{Li}$ and his colleagues (Li et al., 2004). By including the maximum and minimum values of the most sensitive factors (i.e., soil texture and SOC content) into the GIS database, DNDC calculated two $\mathrm{CH}_{4}$ fluxes for each grid cell. The two extreme $\mathrm{CH}_{4}$ fluxes formed a range, within which the "real" flux should be located with a high probability. With this methodology, we concluded that the regional $\mathrm{CH}_{4}$ emission ranged between 0.43 and $0.58 \mathrm{Tg} \mathrm{CH}_{4}-\mathrm{C}$; i.e., the standard deviation was $\pm 14 \%$. According to the 2006 IPCC Guidelines, a baseline emission factor for no flooded fields for less than 180 days prior to rice cultivation and continuously flooded during the rice cultivation period without organic amendments $(\mathrm{EFc})$ is used as a starting point (IPCC, 2006). The IPCC default for $\mathrm{EFc}$ is $1.30 \mathrm{~kg} \mathrm{CH}_{4}$ ha day ${ }^{-1}$ which was estimated by a statistical analysis of available field measurement data
(Yan et al., 2005). In the Sanjiang Plain, for 1.44 million ha of paddy fields in 2006, and a total of 106-day continuously flooded without organic amendments was assumed to practice during the rice-growing season. Consequently, the total methane emissions in 2006 based on the IPCC default emission factors were approximately $0.20 \mathrm{Tg} \mathrm{CH}_{4}-\mathrm{C}$, which is significantly lower than the modeled estimation in this study (0.53 $\left.\mathrm{Tg} \mathrm{CH}_{4}-\mathrm{C}\right)$. Explaining such large differences in $\mathrm{CH}_{4}$ emissions would become a continuously interesting research topic in the future on regional estimation of $\mathrm{CH}_{4}$ emissions from the rice-producing region with the highest latitude.

Studies on greenhouse gas inventory and mitigation in China were started relatively later in comparison with some other countries. However, the new research campaigns in the direction are being rapidly developed in the country during the recent years driven by the social and research demands. The results reported in the paper is one of the attempts to try to absorb the world advanced techniques such as biogeochemical models, remote sensing mapping, uncertainty analysis to serve the national environmental issues in China.

Acknowledgements. This work was funded by the frontier project of the Northeast Institute of Geology \& Agroecology, Chinese Academy Sciences (No. KZCX3-SW-NA09-05), the Knowledge Innovation Project of The Chinese Academy of Sciences (KZCX2YW-Q06-03) and National Natural Science Foundation of China (No. 41001202). The participation of Changsheng Li in the study was supported by NASA's ROSE TE project "Modeling impacts of climate change on carbon dynamics in northern high latitude wetlands" (NNX09AQ36G).

Edited by: X. Wang

\section{References}

Aggarwal, P. K., Kalra, N., Chander, S., and Pathak, H.: InfoCrop: A generic simulation model for annual crops in tropical environments, Indian Agricultural Research Institute, New Delhi, 2004.

Anastasi, C., Dowding, M., and Simpson, V. J.: Future CH4 emission from rice production, J. Geophys. Res., 97, 7521-7125, 1992.

Babu, Y. J., Li, C. S., Frolking, S., Nayak, D. R., Datta, A., and Adhya, T. K.: Modelling of methane emissions from rice-based production systems in India with the denitrification and decomposition model: field validation and sensitivity analysis, Curr. Sci., 89, 1904-1912, 2005.

Babu, Y. J., Li, C. S., Frolking, S., Nayak, D. R., and Adhya, T. K.: Field validation of DNDC model for methane and nitrous oxide emissions from rice-based production systems of India, Nutr. Cycl. Agroecosys., 74, 157-174, 2006.

Bachelet, D., and Neue, H. U.: Methane emission from wetland rice areas of Asia, Chemosphere, 26, 219-237, 1993.

Blake, D. R. and Rowland, F. S.: Continuing worldwide increase in tropospheric methane, 1978-1987, Science, 239, 1129-1131, 1998. 
Cai, Z. C., Xing, G. X., Shen, G. Y., Xu, H., Yan, X. Y., and Tsuruta, H.: Measurements of $\mathrm{CH}_{4}$ and $\mathrm{N}_{2} \mathrm{O}$ emissions from rice paddies in Fengqiu, China, Soil Sci. Plant Nutr., 45, 1-13, 1999.

Cai, Z. C., Tsuruta, H., and Minami, K.: Methane emission from rice fields in China: measurements and influencing factors, J. Geophys. Res., 105, 17231-17242, 2000.

Cai, Z. C., Sawamoto, S., Li, C. S., Kang, G., Boonjawat, J., Mosier, A., and Wassmann, R.: Field validation of the DNDC model for greenhouse gas emissions in East Asian cropping systems, Global Biogeochem. Cy., 17, 1107, doi:10.1029/2003GB002046, 2003.

Cao, M., Dent, J. B., and Heal, O. W.: Modelling of methane emission from rice paddies, Global Biogeochem. Cy., 9, 183-195, 1995a.

Cao, M., Dent, J. B., and Heal, O. W.: Methane emissions from China's paddyland, Agric. Ecosys. Environ., 55, 129-137, 1995b.

Cao, M., Gregson, K., Marshall, S., Dent, J. B., and Heal, O. W.: Global methane emissions from rice paddies, Chemosphere, 33, 879-897, 1996.

Cao, M., Gregson, K., and Marshall, S.: Global methane emissions from wetlands and its sensitivity to climate change, Atmos. Environ., 32, 3293-3299, 1998.

Cole, V., Cerri, C., Minami, K., Mosier, A., Rosenberg, N., and Sauerbeck, D.: Agricultural options for mitigation of greenhouse gas emissions, in: Climate Change 1995: Impacts, adaptations and mitigation of climate change: Scientific-Technical Analyses, edited by: Watson, R. T., Cambridge University Press, Cambridge, 1996.

Dlugokencky, E. J., Masarie, K. A., Lang, P. M., and Tans, P. P.: Continuing decline in the growth rate of the atmospheric methane burden, Nature, 393, 447-450, 1998.

Etheridge, D., Pearman, G., and Fraser, P.: Changes in tropospheric methane between 1841 and 1978 from a high accumulation-rate Antarctic ice core, Tellus, 44B, 282-294, 1992.

FAO: FAO statistical databases, available at: http://faostat.fao.org/ (verified 9 Feb. 2006), Rome, 2004.

Frolking, S., Qiu, J., S., B., Xiao, X., Liu, J., Zhuang, Y., Li, C. S., and Qin, X.: Combining remote sensing and ground census data to develop new maps of the distribution of rice agriculture in China, Global Biogeochem. Cy., 16, 1091, doi:10.1029/2001GB001425, 2002.

Giltrap, D. L., Li, C. S., and Saggar, S.: DNDC: A process-based model of greenhouse gas fluxes from agricultural soils, Agric. Ecosys. Environ., 136, 292-230, 2010.

Holzapfel-Pschorn, A., and Seiler, W.: Methane emission during a cultivation period from an Italian rice paddy, J. Geophys. Res., 91, 11803-11814, 1986.

IPCC: Revised 1996 IPCC Guidelines for National Greenhouse Gas Inventories Workbook, Vol. 2, Intergovernmental Panel on Climate Change, Cambridge University Press, Cambridge, 1997.

IPCC: 2006 IPCC Guidelines for National Greenhouse Gas Inventories, Vol. 4, Prepared by the National Greenhouse Gas Inventories Programme, edited by: Eggleston, H. S., Buendia, L., Miwa, K., Ngara, T., and Tanabe, K., the Institute for Global Environmental Strategies (IGES), Hayama, 2006.

IPCC: The physical science basis. In: Contribution of working group I to the fourth assessment report of the intergovernmental panel on climate change, Intergovernmental Panel on Climate
Change, Cambridge University Press, Cambridge, 2007.

Kern, J. S., Gong, Z., Zhang, G., Zhuo, H., and Luo, G.: Spatial analysis of methane emissions from paddy soils in China and the potential for emissions reduction, Nutr. Cycl. Agroecosys., 49, 181-195, 1997.

Khalil, M. A. K., Rasmussen, R. A., Wang, M. X., and Ren, L. X.: Methane emission from rice fields in China, Environ. Sci. Technol., 25, 979-981, 1991.

Le Toan, T., Ribbes, F., Wang, L. F., Nicolas, F., Ding, K. H., Kong, J. A., Fujita, M., and Kurosu, T.: Rice crop mapping and monitoring using ERS-1 data based on experiment and modeling results, IEEE T. Geosci. Remote, 35, 41-56, 1997.

Li, C. S., Frolking, S., and Frolking, T. A.: A model of nitrous oxide evolution from soil driven by rainfall events. 2. Model applications, J. Geophys. Res., 97, 9777-9783, 1992a.

Li, C. S., Frolking, S., and Frolking, T. A.: A model of nitrous oxide evolution from soil driven by rainfall events: I. Model structure and sensitivity, J. Geophys. Res., 97, 9759-9776, 1992b.

Li, C. S., Frolking, S., and Harriss, R. C.: Modeling carbon biogeochemistry in agricultural soils, Global Biogeochem. Cy., 8, 237-254, 1994.

Li, C. S.: Modeling trace gas emissions from agricultural ecosystems, Nutr. Cycl. Agroecosys., 58, 259-276, 2000.

Li, C. S., Qiu, J., Frolking, S., Xiao, X., Salas, W., Moore III, B., Boles, S., Huang, Y., and Sass, R.: Reduced methane emissions from largescale changes in water management in China's rice paddies during 1980-2000, Geophys. Res. Lett., 29, 1972, doi:10.1029/2002GL015370, 2002.

Li, C. S., Mosier, A., Wassmann, R., Cai, Z., Zheng, X., Huang, Y., Tsuruta, H., Boonjawat, J., and Lantin, R.: Modeling greenhouse gas emissions from rice-based production systems: sensitivity and upscaling, Global Biogeochem. Cy., 18, GB1043, doi:10.1029/2001GB001425, 2004.

Li, C. S., Salas, W., DeAngelo, B., and Rose, S.: Assessing alternatives for mitigating net greenhouse gas emissions and increasing yields from rice production in China over the next 20 years, J. Environ. Qual., 35, 1554-1565, 2006.

Matthews, R. B., Wassmann, R., and Arah, J.: Using a crop/soil simulation model and GIS techniques to assess methane emsissions from rice fields in Asia, I. Model development, Nutr. Cycl. Agroecosys., 58, 141-159, 2000.

Neue, H. U.: Methane emission from rice fields, Biosciences, 43, 466-474, 1993.

Oenema, O., Velthof, G., and Kuikman, P.: Technical and policy aspects of strategies to decrease greenhouse gas emissions from agriculture, Nutr. Cycl. Agroecosys., 60, 301-315, 2001.

Pathak, H., Li, C., and Wassmann, R.: Greenhouse gas emissions from Indian rice fields: calibration and upscaling using the DNDC model, Biogeosciences, 2, 113-123, doi:10.5194/bg-2113-2005, 2005.

Ribbes, F. and Le Toan, T.: Rice field mapping and monitoring with RADARSAT data, Int. J. Remote Sens., 20, 745-765, 1999.

Salas, W., Boles, S., Li, C. S., Babu, Y., Xiao, X., Frolking, S., and Green, P.: Mapping and modeling of greenhouse gas emissions from paddies with satellite radar observations and the DNDC biogeochemical model, Aquat. Conserv., 17(3), 319-329, 2007.

Sass, R. L., Fisher, F. M., Wang, Y. B., Turner, F. T., and Jund, M. F.: Methane emission from rice fields: The effect of flood water management, Global Biogeochem. Cy., 6, 249-262, 1992. 
Scheehle, E. A. and Kruger, D.: Global anthropogenic methane and nitrous oxide emissions, Energy J., 22, 33-44, 2006.

Shi, X. Z., Yu, D. S., Warner, E. D., Pan, X. Z., Petersen, G. W., Gong, Z. G., and Weindorf, D. C.: Soil database of 1:1,000,000 digital soil survey and reference system of the Chinese genetic soil classification system, Soil Surv. Horiz., 45, 129-136, 2004.

Sinha, S. K.: Methane emission from rice paddies: excellent methodology but poor extrapolation, Curr. Sci., 68, 643-646, 1995

Smith, P., Smith, J. U., Powlson, D. S., McGill, W. B., Arah, J. R. M., Chertov, O. G., Coleman, K., Franko, U., Frolking, S., Jenkinson, D. S., Jensen, L. S., Kelly, R. H., Klein-Gunnewiek, H., Komarov, A. S., Li, C., Molina, J. A. E., Mueller, T., Parton, W. J., Thornley, J. H. M., and Whitmore, A. P.: A comparison of the performance of nine soil organic matter models using datasets from seven long-term experiments, Geoderma, 81, 153225, 1997.

Takeuchi, W., Yasuoka, Y., and Tamura, M.: Estimation of Mehtane Emission from Paddy Fields in Central Plain of Thailand by Scaling Technique. In: Proceedings of the 22nd Asian Conference on Remote Sensing, 5-9 November 2001, Singapore, 1, 422-427, 2001.

USEPA: Global anthropogenic non- $\mathrm{CO}_{2}$ greenhouse gas emissions: 1990-2020 (June 2006 Revised), available at: http://www.epa.gov/climatechange/economics/downloads/ GlobalAnthroEmissionsReport.pdf, Office of Atmospheric Programs, USEPA, Washington, DC, 2006.

Van Bodegom, P. M. and Scholten, J. C. M.: Microbial processes of $\mathrm{CH}_{4}$ production in a rice paddy soil: model and experimental validation, Geochim. Cosmochim. Ac., 65, 2055-2066, 2001.

Verburg, P. H. and Van Der Gon, H. A. C. D.: Spatial and temporal dynamics of methane emissions from agricultural sources in China, Glob. Change Biol., 7, 31-47, 2001.

Verburg, P. H., van Bodegom, P. M., van der Gon, H. A. C. D., Bergsma, A., and van Breemen, N.: Upscaling regional emissions of greenhouse gases from rice cultivation: Methods and sources of uncertainty, Plant Ecol., 182, 89-106, 2006.

Wang, Y., Chen, W., Zhao, Z., and Gu, J.: Characteristics and estimation of $\mathrm{CH}_{4}, \mathrm{~N}_{2} \mathrm{O}$ emission from cold paddy field in the Sanjiang Plain, Trans. CSAE, 24, 170-176, 2008. (in Chinese with English abstract)
Wassmann, R., Neue, H. U., and Bueno, C.: Methane production capacities of different rice soils derived from inherent and exogenous substrates, Plant Soil, 203, 227-237, 1998.

Xiao, X., Boles, S., Liu, J., Zhuang, D., Frolking, S., Li, C., Salas, W., and Moore III, B.: Mapping paddy rice agriculture in southern China using multi-temporal MODIS images, Remote Sens. Environ., 95, 480-492, 2005.

Yagi, K. and Minami, K.: Effect of organic matter application on methane emission from some Japanese rice fields, Soil Sci. Plant Nutr., 36, 599-610, 1990.

Yagi, K., Tsuruta, H., Kanda, K., and Manami, K.: Effect of water management on methane emission from a Japanese rice field: Automated methane monitoring, Global Biogeochem. Cy., 10, 255-267, 1996.

Yan, X. Y., Yagi, K., Akiyama, H., and Akimoto, H.: Statistical analysis of the major variables controlling methane emission from rice fields, Glob. Change Biol., 11, 1131-1141, 2005.

Yao, H. and Chen, Z. L.: Effect of chemical fertilizer on methane emission from rice paddies, J. Geophys. Res., 99, 16463-16470, 1994.

Yao, H., Zhuang, Y., and Chen, Z. L.: Estimation of methane emission from rice paddies in Mainland China, Global Biogeochem. Cy., 10, 641-649, 1996.

Yu, D. S., Shi, X. Z., Wang, H. J., Sun, W. X., Chen, J. M., Liu, Q. H., and Zhao, Y. C.: Regional patterns of soil organic carbon stocks in China, J. Environ. Manage., 85, 680-689, 2007.

Zhang, Y., Li, C., Zhou, X., and Moore III, B.: A simulation model linking crop growth and soil biogeochemistry for sustainable agriculture, Ecol. Model., 151, 75-108, 2002.

Zhang, L., Yu, D., Shi, X., Weindorf, D., Zhao, L., Ding, W., Wang, H., Pan, J., and Li, C.: Quantifying methane emissions from rice fields in the Taihu Lake region, China by coupling a detailed soil database with biogeochemical model, Biogeosciences, 6, 739749, doi:10.5194/bg-6-739-2009, 2009a.

Zhang, Y., Wang, C., Wu, J., Qi, J., and Salas, A. W.: Mapping paddy rice with multi-temporal ALOS PALSAR imagery in southeast China, Int. J. Remote Sens., 30, 6301-6315, 2009b.

Zheng, X. H., Wang, M. X., Wang, Y. S., Shen, R. X., Shangguan, X. J., Heyer, J., Kogge, M., Papen, H., Jin, J. S., and Li, L. T.: $\mathrm{CH}_{4}$ and $\mathrm{N}_{2} \mathrm{O}$ emissions from rice paddies in southeast China, Chin. J. Atmos. Sci., 21, 167-174, 1997. 